\title{
PERBEDAAN HUBUNGAN PENGETAHUAN DENGAN PERILAKU PEDAGANG PASAR JOMBANG TENTANG PENCEGAHAN COVID 19
}

\author{
Sylvie Puspita ${ }^{1}$, Enny Puspita ${ }^{2}$ \\ ${ }^{1,2}$ Prodi Ners, Sekolah Tinggi Ilmu Kesehatan Husada Jombang
}

\begin{abstract}
Covid-19 is an infectious disease that is currently happening all over the world.. There needs to be support from various parties in breaking the chain of spread. Marketi s one of the places that can be a transmission of Covid-19 transmission. The research method used in this research is correlation analytic with cross sectional approach where researchers used a questionnaire and observation sheet on the behavior of market traders regarding the prevention of covid-19. The population in this study were 414 traders of the Ploso traditional market, Jombang district. The sample in this study was the Ploso traditional market traders who were 100 respondents at the time of the study and 100 respondents in the peterongan market. The sampling technique used in this research is accidental sampling. Based on the results of the statistical test of sperm rank in the ploso market, the pvalue of 0.00 is less than 0.05, which means that there is a relationship between market traders' knowledge and covid-19 prevention behavior with a moderate level of 0.575. The results of the ploso market statistical test, p-value of 0.085, are more than 0.05, which means that there is no relationship between market traders' knowledge and COVID-19 prevention behavior.
\end{abstract}

Covid-19; Knowledge: Preventive Behavior ; Market Trader

\section{A. PENDAHULUAN}

Coronavirus Disease 2019 (COVID-19) adalah penyakit menular yang disebabkan oleh Severe Acute Respiratory Syndrome Coronavirus 2 (SARSCoV-2). SARS-CoV-2 merupakan coronavirus jenis baru yang belum pernah diidentifikasi sebelumnya pada manusia (Kemenkes RI 2020-Rev 5). Ada setidaknya dua jenis coronavirus yang diketahui menyebabkan penyakit yang dapat menimbulkan gejala berat seperti Middle East Respiratory Syndrome (MERS) dan Severe Acute Respiratory Syndrome (SARS) (Kemenkes , 2020)

Covid-19 merupakan penyakit menular yang saat ini sedang terjadi di seluruh dunia. Perlu adanya dukungan dari berbagi pihak dalam memutus rantai penyebaran. Pasar merupakan salah satu tempat yang bisa menjadi transmisi penularan Covid-19 (Tetartor et al., 2021). Hal ini karena proses interaksi dan transaksi yang terjadi di dalam pasar memudahkan transmisi penyebaran. Salah satu cara untuk memutus rantai penularan dengan penerapan perilaku pencegahan Covid-19(Natun et al., 2021).

Masalah yang terjadi dilapangan adalah masih buruknya Perilaku pedagang pasar tradisonal yang belum menggunakan masker secara konsisten dan sulitnya menjaga jarak menyebabkan angka penularan Covid-19 dipasar menjadi salah satu tempat yang rawan dalam penularan Covid-19 hal ini. Berdasarkan berita sariagri per agustus 2020 klaster covid rata-rata didominasi kluster pasar tradisional, baik yang berada di Pasar Peterongan dan Pasar Mojoagung. Setiap hari, penambahan kasus 
COVID-19 di Jombang, bisa mencapai angka 5 hingga 8 kasus. Bahkan dari total kasus yang saat ini mencapai angka 386 tersebut, 86 merupakan tambahan dalamdua pekan terakhir.

Tujuan dalam penelitian ini adalah untuk menganalisis Pengetahuan Pedagang Dengan Motivasi Dan Perilaku Pencegahan Penyebaran Covid-19 Di Pasar Kabupaten Jombang (Kec.Peterongan, Kec.Peterongan ).

\section{B. TINJAUAN PUSTAKA}

\section{a. Definisi}

Coronavirus Disease 2019 atau COVID-19 adalah penyakit baru yang dapat menyebabkan gangguan pernapasan dan radang paru. Penyakit ini disebabkan oleh infeksi Severe Acute Respiratory Syndrome Coronavirus 2 (SARS-CoV-2). Gejala klinis yang muncul beragam, mulai dari seperti gejala flu biasa (batuk, pilek, nyeri tenggorok, nyeri otot, nyeri kepala) sampai yang berkomplikasi berat (pneumonia atau sepsis) (Diskominfotik, 2020). Virus korona termasuk keluarga besar virus yang menyebabkan sakit, dari yang ringan seperti flu biasa hingga sakit serius dan mematikan. Ada tujuh jenis virus pada manusia dari Alphacoronavirus hingga 2019-nCoV. Dari tujuh jenis tersebut, baru Betacoronavirus dan 2019-nCoV yang memicu wabah. Betacoronavirus menyebabkan Sindrom Pernafasan Akut Parah (SARS) dan Sindrom Pernafasan Timur Tengah (MERS). Sedangkan virus 2019nCoV menyebabkan penyakit yang disebut sindrom pernafasan akut akibat virus korona baru (Irawaty, 2020).

\section{b. Etiologi}

Penyebab COVID-19 adalah virus yang tergolong dalam family coronavirus. Coronavirus merupakan virus RNA strain tunggal positif, berkapsul dan tidak bersegmen. Terdapat 4 struktur protein utama pada Coronavirus yaitu: protein $\mathrm{N}$ (nukleokapsid), glikoprotein $\mathrm{M}$ (membran), glikoprotein spike S (spike), protein E (selubung). Coronavirus tergolong ordo Nidovirales, keluarga Coronaviridae. Coronavirus ini dapat menyebabkan penyakit pada hewan atau manusia. Terdapat 4 genus yaitu alphacoronavirus, betacoronavirus, gammacoronavirus, dan deltacoronavirus. Sebelum adanya COVID-19, ada 6 jenis coronavirus yang dapat menginfeksi manusia, yaitu $\mathrm{HCoV}-229 \mathrm{E}$ (alphacoronavirus), HCoV-OC43 (betacoronavirus), HCoVNL63 (alphacoronavirus) HCoV-HKU1 (betacoronavirus), SARS-CoV (betacoronavirus), dan MERS-CoV (betacoronavirus) (Shereen, et al, 2020) 


\section{CARA PENULARAN VIRUS CORONA}

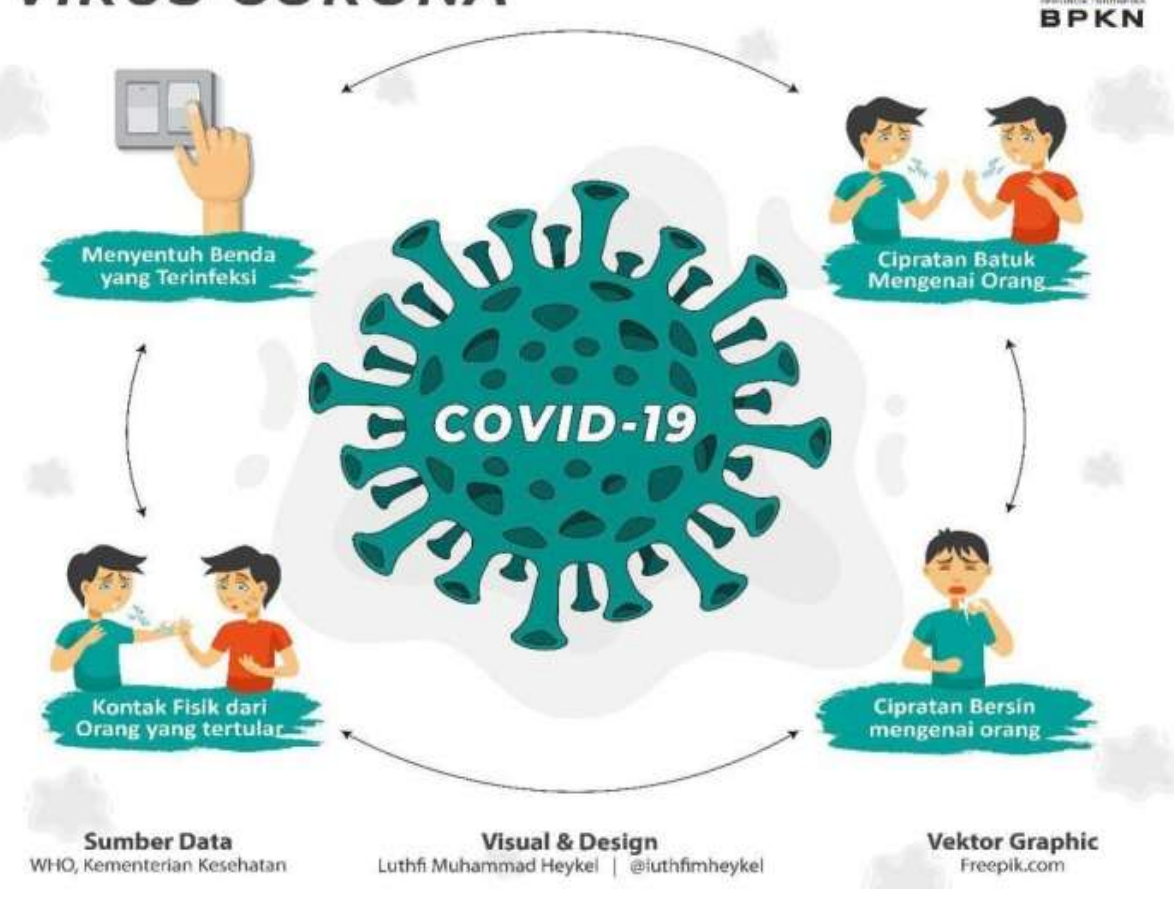

Gambar Proses Penularan Virus Covid-19

\section{c. Gejala Infeksi Coronavirus}

Menurut IDI (2020), Virus corona bisa menimbulkan beragam gejala pada pengidapnya. Gejala yang muncul ini bergantung pada jenis virus corona yang menyerang, dan seberapa serius infeksi yang terjadi. Berikut beberapa gejala virus corona yang terbilang ringan:

a) Hidung beringus.

b) Sakit kepala.

c) Batuk.

d) Sakit tenggorokan.

e) Demam.

f) Merasa tidak enak badan.

WHO (2020) menyatakan bahwa hal yang perlu ditegaskan, beberapa virus corona dapat menyebabkan gejala yang parah. Infeksinya dapat berubah menjadi bronkitis dan pneumonia (disebabkan oleh 2019-nCoV)

\section{METODE PENELITIAN}

Desain penelitian yang digunakan dalam penelitian ini adalah survey analitik dengan rancangan Cross Sectional. Populasi dalam penelitian ini adalah pedagang pasar tradisonal Ploso kabupaten Jombang sejumlah 414. Sampel dalam penelitian ini adalah 
pedagang pasar tradisonal Ploso yang ada pada saat penelitian sejumlah 100 responden dan pasar peterongan 100 responden. Teknik sampling yang digunakan dalam penelitian ini adalah acidental sampling. Variabel independent dalam penelitian ini adalah pengetahuan tentang Covid-19 dan variabel dependent adalah perilaku pencegahan Covid-19 pada pedagang pasar tradisonal. Instrumen yang digunakan dalam penelitian ini adalah kuisoner pengetahuan pedagang pasar yang terdiri dari 15 pertanyaan dengan hasil uji validitas dan realibilitas 0,797 dan lembar observasi perilaku pencegahan Covid-19 yang terdiri dari 8 item ceklist. Pelaksanaan penelitian dilakukan selama 14 hari untuk mendapatkan 200 responden mengingat peneliti juga harus melakukan penelitian disela-sela pedagang berjualan. Dalam Prosedur penelitian Sebelum penelitian peneliti melakukan ijin kepada dinas perdagangan dan perindustrian kabupaten jombang untuk dilakukan penelitian di pasar wilayah Jombang khususnya Pasar Ploso dan Peterongan. Selanjutnya pengolahan data di mulai dari editing, coding, scoring dan tabulating. Uji statistik menggunakan spss for window versi 20 dengan anlisis statistik sperman rank Peneliti sudah melakukan uji etik penelitian di komisi etik Sekolah Tinggi Ilmu Kesehatan Husada Jombang dengan no 0113-KEPKSHJ.

\section{HASILPENELITIAN}

\section{Data Umum}

Tabel 1 Karakteristik Responden Pasar Ploso

\begin{tabular}{|c|c|c|c|}
\hline No & Kategori & frekuensi & Presentase \\
\hline \multirow[t]{4}{*}{1} & Jenis kelamin & & \\
\hline & 1. Laki-laki & 26 & $26 \%$ \\
\hline & 2. Perempuan & 74 & $74 \%$ \\
\hline & Jumlah & 100 & $100 \%$ \\
\hline \multirow[t]{7}{*}{2} & Umur & & \\
\hline & 1. $21-30$ & 4 & $4 \%$ \\
\hline & 2. $41-40$ & 22 & $22 \%$ \\
\hline & 3. $41-50$ & 42 & $42 \%$ \\
\hline & 4. $51-60$ & 21 & $21 \%$ \\
\hline & 5. $>61$ & 11 & $11 \%$ \\
\hline & Jumlah & 100 & $100 \%$ \\
\hline \multirow[t]{6}{*}{3} & Pendidikan & & \\
\hline & 1. $\mathrm{SD}$ & 19 & $19 \%$ \\
\hline & 2. SMP & 27 & $27 \%$ \\
\hline & 3. SMA & 52 & $52 \%$ \\
\hline & 4. PT & 2 & $2 \%$ \\
\hline & Jumlah & 100 & $100 \%$ \\
\hline 4 & Pernah mendapatkan sumber & & \\
\hline
\end{tabular}




\begin{tabular}{|c|c|c|c|}
\hline & $\begin{array}{l}\text { informasi } \\
\text { 1. Pernah } \\
\text { 2. Tidak pernah } \\
\text { Jumlah }\end{array}$ & $\begin{array}{c}57 \\
43 \\
100\end{array}$ & $\begin{array}{l}57 \% \\
43 \% \\
100 \%\end{array}$ \\
\hline 5 & $\begin{array}{l}\text { Sumber informasi } \\
\text { 1. tenaga kesehatan } \\
\text { 2. keluarga atau teman } \\
\text { 3. media sosial } \\
\text { 4. televisi/radio } \\
\text { 5. berita (online/cetak) } \\
\text { Jumlah }\end{array}$ & $\begin{array}{c}19 \\
27 \\
52 \\
2 \\
100\end{array}$ & $\begin{array}{c}19 \% \\
27 \% \\
52 \% \\
2 \% \\
100 \%\end{array}$ \\
\hline 6 & $\begin{array}{l}\text { Apakah pernah sakit covid } \\
\text { 1. pernah } \\
\text { 2. tidak pernah } \\
\text { Jumlah }\end{array}$ & $\begin{array}{c}2 \\
98 \\
100\end{array}$ & $\begin{array}{r}2 \% \\
98 \% \\
100 \%\end{array}$ \\
\hline 7 & $\begin{array}{l}\text { Apakah keluarga pernah sakit } \\
\text { covid } \\
\text { 1. pernah } \\
\text { 2. tidak pernah } \\
\text { Jumlah }\end{array}$ & $\begin{array}{c}2 \\
98 \\
100\end{array}$ & $\begin{array}{l}2 \% \\
98 \% \\
100 \%\end{array}$ \\
\hline 8 & $\begin{array}{l}\text { Lama berjualan dipasar: } \\
\text { 1. } 5 \text { tahun } \\
\text { 2. 6-10 tahun } \\
\text { 3. } 11-20 \text { tahun } \\
\text { 4. } 21-30 \text { tahun } \\
\text { 5. }>31 \\
\text { Jumlah }\end{array}$ & $\begin{array}{c}20 \\
17 \\
9 \\
53 \\
1 \\
100\end{array}$ & $\begin{array}{c}20 \% \\
17 \% \\
9 \% \\
53 \% \\
1 \% \\
100 \%\end{array}$ \\
\hline 9 & $\begin{array}{l}\text { Jumlah keluarga } \\
\text { 1. } \leq 3 \text { orang } \\
\text { 2. }>3 \text { orang }\end{array}$ & $\begin{array}{c}18 \\
82 \\
100\end{array}$ & $\begin{array}{l}18 \% \\
82 \% \\
100 \%\end{array}$ \\
\hline 10 & $\begin{array}{l}\text { Penghasilan tiap bulan } \\
\text { 1. } 1-2 \text { juta } \\
\text { 2. } 2-3 \text { juta }\end{array}$ & $\begin{array}{l}83 \\
14\end{array}$ & $\begin{array}{l}83 \% \\
14 \%\end{array}$ \\
\hline
\end{tabular}




\begin{tabular}{|l|l|c|c|}
\hline & $3 . \geq 3$ juta & 3 & $3 \%$ \\
& & 100 & $100 \%$ \\
\hline
\end{tabular}

Berdasarkan tabel 1 didapatkan hasil sebagian besar pedagang berjenis ploso berjenis kelamin perempuan 74 (74\%) dan sebagian kecil berjenis kelamin laki-laki 26 $(26 \%)$. Berdasarkan umur pedagang hampir setengahnya berumur $41-50$ tahun $(42 \%)$ dan sebaian kecil ber usia 21-30 tahub (4\%). Berdasrkan pendidikan setengahnya berpendidikan SMA 52 orang (52\%) dan sebagian kecil berpendidikan PT 2 orang (2\%). Sumber informasi tentang covid sebagian besar sudah pernah mendapatkan info 57 responden $(57 \%)$. Berdasarkan sumber informasi sebagian besar mendapatkannya dari televisi atau radio 52 responden (52\%). Berdasarkan pengalaman apakah pernah sakit covid sebagian besar responden tidak pernah sebanyak 98 responden (98\%) pengalaman keluarga yang pernh menderita covid sebagian besar keluarga tidak pernah menderita covid-19 98 orang (98\%) berdasarkan lama berjualan dipasar setengahnya sudah berjualan 21-30 tahun

Tabel 1. Karakteristik Responden Pasar Peterongan.

\begin{tabular}{|c|c|c|c|}
\hline No & Kategori & frekuensi & Presentase \\
\hline \multirow[t]{4}{*}{1} & Jenis kelamin & & \\
\hline & 1. Laki-laki & 40 & $40 \%$ \\
\hline & 2. Perempuan & 60 & $60 \%$ \\
\hline & Jumlah & 100 & $100 \%$ \\
\hline \multirow[t]{8}{*}{2} & Umur & & \\
\hline & 1. $<20$ & 1 & $1 \%$ \\
\hline & 2. $21-30$ & 18 & $18 \%$ \\
\hline & 3. $41-40$ & 29 & $29 \%$ \\
\hline & 4. $41-50$ & 32 & $32 \%$ \\
\hline & 5. $51-60$ & 14 & $14 \%$ \\
\hline & 6. $>61$ & 5 & $5 \%$ \\
\hline & Jumlah & 100 & $100 \%$ \\
\hline \multirow[t]{6}{*}{3} & Pendidikan & & \\
\hline & 1. SD & 19 & $19 \%$ \\
\hline & 2. SMP & 27 & $27 \%$ \\
\hline & 3. SMA & 52 & $52 \%$ \\
\hline & 4. PT & 2 & $2 \%$ \\
\hline & Jumlah & 100 & $100 \%$ \\
\hline 4 & $\begin{array}{l}\text { Pernah mendapatkan } \\
\text { sumber informasi }\end{array}$ & & \\
\hline
\end{tabular}




\begin{tabular}{|c|c|c|c|}
\hline & $\begin{array}{l}\text { 1. Pernah } \\
\text { 2. Tidak pernah } \\
\text { Jumlah }\end{array}$ & $\begin{array}{c}77 \\
23 \\
100\end{array}$ & $\begin{array}{l}77 \% \\
23 \% \\
100 \%\end{array}$ \\
\hline 5 & $\begin{array}{l}\text { Sumber informasi } \\
\text { 1. tenaga kesehatan } \\
\text { 2. keluarga atau teman } \\
\text { 3. media sosial } \\
\text { 4. televisi/radio } \\
\text { 5. berita (online/cetak) } \\
\text { Jumlah }\end{array}$ & $\begin{array}{c}27 \\
12 \\
24 \\
37 \\
0 \\
100\end{array}$ & $\begin{array}{l}27 \\
12 \\
24 \\
37 \\
0\end{array}$ \\
\hline 6 & $\begin{array}{l}\text { Apakah pernah sakit } \\
\text { covid } \\
\text { 1. pernah } \\
\text { 2. tidak pernah } \\
\text { Jumlah }\end{array}$ & $\begin{array}{c}3 \\
97 \\
100\end{array}$ & $\begin{array}{r}3 \% \\
97 \% \\
100 \%\end{array}$ \\
\hline 7 & $\begin{array}{l}\text { Apakah keluarga } \\
\text { pernah sakit covid } \\
\text { 1. pernah } \\
\text { 2. tidak pernah } \\
\text { Jumlah }\end{array}$ & $\begin{array}{c}4 \\
96 \\
100\end{array}$ & $\begin{array}{c}4 \% \\
96 \% \\
100 \%\end{array}$ \\
\hline 8 & $\begin{array}{l}\text { Lama berjualan dipasar } \\
\text { 1. } 5 \text { tahun } \\
\text { 2. 6-10 tahun } \\
\text { 3. 11-20 tahun } \\
\text { 4. 21-30 tahun } \\
\text { 5. >31 } \\
\text { Jumlah }\end{array}$ & $\begin{array}{c}25 \\
26 \\
19 \\
25 \\
5 \\
100\end{array}$ & $\begin{array}{c}25 \% \\
26 \% \\
19 \% \\
25 \% \\
5 \% \\
100 \%\end{array}$ \\
\hline 9 & $\begin{array}{l}\text { Jumlah keluarga } \\
\text { 1. } \leq 3 \text { orang } \\
\text { 2. }>3 \text { orang }\end{array}$ & $\begin{array}{c}39 \\
61 \\
100\end{array}$ & $\begin{array}{l}39 \% \\
61 \% \\
100 \%\end{array}$ \\
\hline 10 & $\begin{array}{l}\text { Penghasilan tiap bulan } \\
\text { 1. 1-2 juta }\end{array}$ & 72 & $72 \%$ \\
\hline
\end{tabular}




\begin{tabular}{|l|l|c|c|}
\hline 2. $2-3$ juta & 23 & $23 \%$ \\
3. $\geq 3$ juta & 5 & $5 \%$ \\
& 100 & $100 \%$ \\
\hline
\end{tabular}

Berdasakan tabel 1 didapatkan hasil sebagian besar pedagang berjenis peterongan berjenis kelamin perempuan $60(60 \%)$ dan sebagian kecil berjenis kelamin laki-laki 40 $(40 \%)$. Berdasarkan umur pedagang hampir setengahnya berumur $41-50$ tahun $(32 \%)$ dan sebaian kecil ber usia $<21$ tahub (1\%). Berdasrkan pendidikan setengahnya berpendidikan SMA 52 orang $(52 \%)$ dan sebagian kecil berpendidikan PT 2 orang (2\%). Sumber informasi tentang covid sebagian besar sudah pernah mendapatkan info 77 responden (77\%). Berdasarkan sumber informasi sebagian besar mendapatkannya dari televisi atau radio 37 responden (37\%). Berdasarkan pengalaman apakah pernah sakit covid sebagian besar responden tidak pernah sebanyak 98 responden $(98 \%)$ pengalaman keluarga yang pernh menderita covid sebagian besar keluarga tidak pernah menderita covid-19 98 orang (98\%) berdasarkan lama berjualan dipasar setengahnya sudah berjualan 6-10 tahun.

\begin{tabular}{|c|l|c|c|}
\hline No & \multicolumn{1}{|c|}{ Kategori } & frekuensi & Presentase \\
\hline 1 & Motivasi & 34 & \\
& 1. Lemah & 2 & $0 \%$ \\
& 2. Sedang & 64 & $8 \%$ \\
& 3. Kuat & 100 & $92 \%$ \\
& Jumlah & & $100 \%$ \\
\hline 2 & Pengetahuan & 59 & \\
& 1. Baik & 39 & $59 \%$ \\
& 2. Cukup & 2 & $39 \%$ \\
& 3. Kurang & 100 & $100 \%$ \\
\hline
\end{tabular}

\section{Hasil Pasar Ploso}

\section{Tabel 2 Hasil Motivasi, Pengetahuan dan Perilaku pencegahan covid-19}

Berdasarkan tabel 2 didapatkan hasil sebagian besar motivasi pedagang pasar untuk melakukan prokes kuat yaitu 64 pedagang pasar (64\%) mempunyai motivasi kuat. Pengetahuan responden sebagian besar berpengetahuan baik sebesar 59 responden $(59 \%)$. 
Hasil Motivasi, Pengetahuan dan Perilaku pencegahan covid-19 di Pasar Peterongan

\begin{tabular}{|c|l|c|c|}
\hline No & \multicolumn{1}{|c|}{ Kategori } & frekuensi & Presentase \\
\hline 1 & Motivasi & & \\
& 4. Lemah & 21 & $21 \%$ \\
& 5. Sedang & 50 & $50 \%$ \\
& 6. Kuat & 21 & $21 \%$ \\
& Jumlah & 100 & $100 \%$ \\
\hline 2 & Pengetahuan & 6 & $6 \%$ \\
& 4. Baik & 37 & $37 \%$ \\
& 5. Cukup & 57 & $57 \%$ \\
& 6. Kurang & 100 & $100 \%$ \\
\hline
\end{tabular}

Berdasarkan tabel 2 didapatkan hasil setengah responden mempunyai motivasi sedang sejumlah 50, sebgaian besar responden mempunyai pengetahuan kurang sejumlah 57 responden dan sebagian besar berperilaku positif sebanyak 54 responden.

Tabel 3. Hasil uji Sperman-Rank Perbedaan hubungan antara pengetahuan tentang covid-19 dengan motivasi pencegahan Covid-19.

\begin{tabular}{|c|l|c|c|}
\hline No & \multicolumn{1}{|c|}{ Kriteria } & Nilai p-value & Korelasi \\
\hline 1 & $\begin{array}{l}\text { Pengetahuan pedagang pasar } \\
\text { tentang covid-19 }\end{array}$ & 0,00 & 0,575 \\
\hline 2 & $\begin{array}{l}\text { Pengetahuan pedagang pasar } \\
\text { tentang covid-19 }\end{array}$ & 0,00 & 0,575 \\
\hline
\end{tabular}

Berdasarkan hasil uji statistik dipasar ploso didapatkan hasil nilai p-value 0,00 kurang dari 0,05 yang artinya ada hubungan antara pengetahuan pedagang pasar dengan perilaku pencegahan covid-19 dengan tingkat keeratan sedang 0.575. Hasil uji statistik pasar ploso p-value 0,085 lebih dari 0,05 yang artinya tidak ada hubungan antara pengetahuan pedagang pasar dengan perilaku pencegahan covid-19

\section{E. PEMBAHASAN}

Berdasarkan tabel 2 responden pasar Ploso Pengetahuan responden sebagian besar kategori kurang 59 responden (59\%). Sedangkan di pasar peterongan sebgaian besar responden mempunyyai pengetahuan kurang sejumlah 57. Pengetahuan merupakan pemahaman partisipan tentang topik yang diberikan. Pengetahuan adalah kemampuan untuk menerima, mempertahankan, dan menggunakan informasi, yang dipengaruhi oleh pengalaman dan keterampilan. Sebagian besar dari pengetahuan yang dimiliki seseorang berasal dari pendidikan baik formal dan informal, pengalaman pribadi maupun orang lain, lingkungan, serta media massa (Moudy et al., 2020). 
Banyak faktor yang mempengaruhi pengetahuan responden tentang pencegahan COVID-19. Menurut Notoatmodjo (2017), faktor-faktor yang mempengaruhi pengetahuan yaitu pendidikan, umur, pekerjaan dan faktor eksternal lainnya. Berdasarkan karakteristik responden diketahui bahwa sebagian besar responden berumur 41-50 tahun. Faktor yang memengaruhi meningkatnya pengetahuan adalah bertambahnya umur seseorang yang mengalami perubahan aspek fisik dan mental (Mubarak, 2017). Umur seseorang dapat memengaruhi tingkat pengetahuan seseorang karena semakin cukup umur, tingkat kematangan dan kekuatan seseorang akan lebih matang dalam berpikir dan bekerja (Dan et al., 2021).

Berdasarkan hasil penelitian dan teori ada keterkaitan atau keselarasan yaitu pada seseorang yang semakin matang usianya akan bertambah pula pengetahuannya. Hal ini didukung pula dari pendidikan responden yang rata-rata SMA, hal ini selaras dengan teori semakin tinggi pendidikan seseorang akan semakin baik pula pengetahuannya. Ada beberapa faktor eksternal yang mempengarui pengetahuan responden yaitu yaitu sumber informasi yang di dapatkan responden mengenai covid19 merupakan salah satu faktor pengetahuan baik responden berpendidikan SD tetapi pengetahuan dan perilakunya baik. Hal ini salah satu yang mempengarui adalah lingkungan atau sumber informasi yang sebelumnya di dapat. Tingkat pendidikan pedagang yang rendah akan berhubungan dalam proses analisis sebuah informasi yang diperoleh yang diwujudkan dalam sebuah tindakan. Hasil ini searah dengan penelitian Riemenda (2021) menunjukkan bahwa semakin tinggi jenjang pendidikan responden maka responden akan semakin patuh dalam penerapan protokol kesehatan Covid-19. Semakin tinggi pendidikan seseorang maka akan berpengaruh terhadap pelaksanaan kesehatan masyarakat, rendahnya pendidikan seseorang akan menyebabkan kurangnya kesadaran orang tersebut dalam peningkatan kesehatannya. Semakin baik pendidikan formal seseorang akan meningkatkan pemahaman orang tersebut tentang pentingnya kesehatan sehingga hal ini akan mempengaruhi kesadaran perilaku kesehatannya (Tetartor et al., 2021)

Berdasarkan perilaku pedagang pasar ploso dalam melakukan prokes mempunyai perilaku positif/baik $57(57 \%)$ dan Perilaku negatif dalam penerapan prokes $43(43 \%)$. Untuk perilaku pedagang pasar peterongan ada 54 responden berprilaku positif. Perilaku adalah segala bentuk aktivitas individu baik dapat yang dapat dilihat langsung maupun yang tidak dapat dilihat oleh orang lain. oleh pihak luar ( Menurut Notoatmojo (2010) dalam penelitiannya mengungkapkan perilaku yang didasarkan pada pengetahuan akan lebih baik dari pada perilaku yang tidak dilandaskan oleh pengetahuan. Beberapa faktor diantaranya yang mempengaruhi terjadinya perilaku individu adalah yaitu sosiopsikologis. Yang termasuk dalam faktor sosio psikologis adalah sikap, emosi dan kepercayaan. Notoatmojo (2010). Hasil penelitian ini sejalan dengan penelitian klinis lainnya yaitu dari 1.102 responden di Indonesia mayoritas berperilaku baik dengan prevalensi 93\%\%.11 Selain itu penelitian lain yang dilaksanakan di Provinsi DKI Jakarta memberikan hasil yang sejalan dengan penelitian ini yaitu 70,3\% responden memiliki perilaku yang baik.13 Simpulan dan Saran Status kesehatan pedagang tradisional terdiri dari 3 orang dalam pengawasan, 3 kasus konfirmasi, dan 80 pedagang yang sehat. Pengetahuan pedagang tradisional mengenai kesehatan dan keselamatan di era COVID-19 sebagian besar mendapat pengetahuan baik yaitu $53(61,6 \%)$. Sikap pedagang tradisional mengenai kesehatan dan keselamatan di era COVID-19 sebagian besar mendapat sikap positif $70(81,4 \%)$. Perilaku pedagang tradisional mengenai keselamatan di era COVID-19 sebagian besar 
mendapat perilaku baik $63(73,3 \%)$.

Pada beberapa pedagang yang tidak patuh akan protokol kesehatan pencegahan covid-19 adalah kurang nya kesadaran akan penting dan bahaya covid-19 alasan utama dalam penerapan adalah adanya hukuman atau pengawasan dari satgas covid untuk menggunakan masker pada saat dipasar. Hal ini yang membuat tidak adanya perubahan perilaku yang lebih langgeng. Masyarakat hanya menggunakan masker pada saat ada petugas dan menurunkan masker disaat setelah selesai. Alasan lain adalah mereka merasa bahwa ada perasaan tidak nyaman dalam menggunakan masker. Walaupun dari segi pengetahuan mereka tau bahwa salah satu pencegahan covid-19 adalah dengan menerapkan protokol kesehatan.

Berdasarkan hasil uji statistik sperman rank didapatkan hasil nilai p-value 0,00 kurang dari 0,05 yang artinya ada hubungan antara pengetahuan pedagang pasar dengan perilaku pencegahan covid-19 dengan tingkat keeratan sedang 0.575. Ada hubungan antara motivasi dengan perilaku pencegahan covid dengan nilai $0,00>0.05$ dengan tingkat keeratan kuat dengan nilai 0,644. Pengetahuan merupakan kunci dari perubahan perilaku, dan individu dapat memperoleh pengetahuan dan ketrampilan melalui proses belajar (Liu et al, 2016). Pengetahuan pedagang pasar mengingat pekerjaan mereka pada faktor esensial yang selalu bersingungan dengan orang lain. Pengetahuan yang mereka harus tau diantaranya $t$ seperti sekarang ini,yang meliputi penyebab covid dan karakteristik virusnya, tanda dan gejala, istilah yang terkait dengan covid, pemeriksaan yang diperlukan dan proses transmisi yang tinggi tentang covid 19 ini berpengaruh terhadap kejadian dan pencegahan penyakit covid-19(Purnamasari,2020). Dengan demikian pengetahuan masyarakat yang masih perlu diluruskan dan perilaku masyarakat yang masih negative agar bisa diupayakan melalui kegiatan pembelajaran melalui Health edukasi oleh pihak-pihak yang berwenang. Kerjasama dalam mengedukasi sangat dibutuhkan misal dengan forum kesehatan desa atau sejenesnya dapat mengambil peran dalam upaya pelaksanaan kegiatan dimaksud.

\section{F. PENUTUP}

Berdasarkan hasil uji statistik dipasar ploso didapatkan hasil nilai p-value 0,00 kurang dari 0,05 yang artinya ada hubungan antara pengetahuan pedagang pasar dengan perilaku pencegahan covid-19 dengan tingkat keeratan sedang 0.575 . Hasil uji statistik pasar ploso p-value 0,085 lebih dari 0,05 yang artinya tidak ada hubungan antara pengetahuan pedagang pasar dengan perilaku pencegahan covid-19

\section{G. DAFTAR PUSTAKA}

Dan, P., Dengan, S., Penggunaan, K., Towards, A., With, C., \& Use, T. H. E. (2021). Jurnal Ilmiah Permas : Jurnal Ilmiah STIKES Kendal. 11, 35-42.

Diskominfotik. 2020. Materi Komunikasi Risiko COVID-19 untuk Fasilitas Pelayanan Kesehatan. World Health Organization Western Pacific Region.

Hidayat. 2017. Metode Penelitian Kesehatan Dan Teknik Analisa Data. Jakarta: Salemba Medika.

IDI. 2020. Panduan Klinis Tata Laksana COVID-19. Jakarta: Ikatan Dokter Indonesia. 
Irawaty. 2020. Mencegah Dampak Kependudukan Akibat Covid-19. Jakarta: Babel Pos.

Kemenkes RI, 2020. Pedoman Kesiapsiagaan Menghadapi Corona Virus Disease (COVID-19), Jakarta: Direktorat Jenderal Pencegahan dan Pengendalian Penyakit Kemetrian Kesehatan RI

Moudy, J., Syakurah, R. A., \& Artikel, I. (2020). Higeia Journal Of Public Health. 4(3), 333346.

Natun, D. A., Junias, M. S., \& Sahdan, M. (2021). Media Kesehatan Masyarakat Pengetahuan Dan Sikap Pedagang Ikan Tentang Upaya Pencegahan Penularan Covid-19 Di Pasar Kasih Kota Media Kesehatan Masyarakat. 3(2), 146-154.

Notoadmojo, Soekidjo, (2014). Ilmu Perilaku Kesehatan. Jakarta : Rineka Cipta 13. Media Kesehatan Masyarakat. 3(2), 146-154.

Pedoman Pencegahan dan Pengendalian Coronavirus Disease (COVID-19) Kemenkes RI 2020Rev 5

Tetartor, R. P., Anjani, I., Simanjuntak, M. R., \& . D. (2021). Faktor-Faktor Yang Berhubungan Dengan Kepatuhan Pedagang Dalam Pelaksanaan Protokol Kesehatan Covid-19 Di Pasar Petisah Kota Medan Sumatera Utara. Jurnal Kesmas Dan Gizi (Jkg), 3(2), 114-122. https://doi.org/10.35451/jkg.v3i2.489

World Health Organization. (2009b). Your 5 Moments for Hand Hygiene. Patient Safety. https://doi.org/10.1111/mec.12729 14.

World Health Organization. (2010). Hand Hygiene Self-Assessment Framework 